\title{
Effects of Cigarette Smoking on White Blood Cells Count and von Willebrand Factor Levels in Male Smokers in Khartoum State
}

\author{
Roaa Babikir Ahmed', Mahdi H. A. Abdalla ${ }^{2 *}$ \\ ${ }^{1}$ Department of Haematology, Faculty of Medical Laboratory Sciences, Al-Neelain University, Khartoum, Sudan \\ ${ }^{2}$ Department of Haematology, Faculty of Medical Laboratory Sciences, Omdurman Ahlia University, Khartoum, Sudan \\ Email: *mahdi_razig@hotmail.com
}

How to cite this paper: Ahmed, R.B. and Abdalla, M.H.A. (2017) Effects of Cigarette Smoking on White Blood Cells Count and von Willebrand Factor Levels in Male Smokers in Khartoum State. Open Access Library Journal, 4: e3506.

https://doi.org/10.4236/oalib.1103506

Received: March 8, 2017

Accepted: June 19, 2017

Published: June 22, 2017

Copyright $\odot 2017$ by authors and Open Access Library Inc.

This work is licensed under the Creative Commons Attribution International License (CC BY 4.0).

http://creativecommons.org/licenses/by/4.0/

\section{(c) (†) Open Access}

\begin{abstract}
Background: Tobacco cigarette smoking is one of the major leading causes of death and essential public health challenge in world over. Elevated von Willebrand factor (vWF) concentrations are associated with an increased risk of ischemic heart disease. High total leukocyte count can promote cardiovascular diseases through multiple pathologic mechanisms, and has been considered as an independent predictor of atherosclerosis and cardiovascular disease. Objective: To assess the effects of cigarette smoking on White blood cells and von Willebrand factor levels in apparently healthy male smokers. Materials and Methods: One hundred subjects were included in this study: 50 were Sudanese male smokers, and the other 50 were controls. All subjects were evaluated to determine the effects of cigarette smoking on White blood cells and von Willebrand factor levels. The TWBCs was determined using Sysmex ${ }^{\circ}$ Kx21-N Analyzer. vWF level was measured using ELISA method. Results: vWF was significantly higher in male smokers compared to non-smokers ( $\mathrm{p}=$ 0.000). Total White Blood cell (TWBC) count was also higher among smoker than nonsmokers $(\mathrm{P}=0.000)$. There were significant correlations between TWBC count and vWF levels with cigarette consumption/day and the duration of smoking. Conclusion: Our results concluded that smoking increases the white blood cell count and von Willebrand factor levels in males.
\end{abstract}

\section{Subject Areas}

Hematology

\section{Keywords}

Sudanese, Smoking, TWBCs, vWF 


\section{Introduction}

Tobacco cigarette smoking is one of the major leading causes of death and essential public health challenge in world over [1] [2]. Smoking has both acute and chronic effect on hematological parameters. There are more than 4000 chemicals found in cigarette smoke [3], and a cigarette smoker is exposed to several harmful substances including nicotine, free radicals, carbon monoxide and other gaseous products [4]. A strong correlation has been found between cigarette smoking and atherosclerosis and cardiovascular disease [5]. Several studies have considered endothelial injury to be a key initiating event in the pathogenesis of cardiovascular disorders [6]. However, the precise pathophysiology of the adverse effects of smoking on endothelium is not very clear. Smoking has also been shown to influence levels of von Willebrand factor protein (vWF). vWF synthesized and stored in endothelial cells and megakaryocytes, has been reported to be a useful marker for endothelial cell damage [7]. This protein, which acts as a carrier and stabilizer for factor VIII, was reported to facilitate platelet aggregation and adhesion to the sub endothelium of an injured vessel wall [8].

vWF is a multimeric glycoprotein that plays an important role in primary haemostasis by promoting platelet adhesion to the sub endothelium at sites of vascular injury under high shear-rate conditions. It is also a carrier of FVIII and this association protects FVIII from rapid proteolysis. vWF is synthesized by endothelial cells, megakaryocytes and platelets. In endothelial cells vWF may be secreted directly into the circulation or stored in Weibel-Palade bodies. The vWF produced in megakaryocytes and platelets is not secreted but stored in alpha-granules. Release of VWF from these stores occurs following activation of endothelial cells or platelets. Some therapeutic products and conditions, may work to stimulate the release of stored vWF [9]. Elevated vWF concentrations are associated with an increased risk of ischemic heart disease [10]. A sufficiently low level of vWF predisposes to bleeding that can be quite serious, and low vWF is a diagnostic feature of von Willebrand disease (VWD) type 1, which is characterized by partial quantitative deficiency of vWF [11]. While leukocytosis may simply be a marker of smoking-induced tissue damage, the high count can promote cardiovascular diseases through multiple pathologic mechanisms that mediate inflammation, plug the microvasculature, induce hypercoagulability and promote infarct expansion [12] [13]. In fact, several studies have shown that WBC count is an independent predictor of atherosclerosis and cardiovascular disease [12] [13]. The aim of this study was to assess the effects of cigarette smoking on White blood cells and von vWF factor levels in apparently healthy male smokers.

\section{Materials and Methods}

This study is a case-control study, conducted in Khartoum, Sudan. One hundred subjects were included in this study, all of them were males, 50 were smokers and the other 50 were apparently healthy age matched nonsmokers (control 
group). Smokers were classified into 3 groups according to the number of cigarettes smoked per day: mild smokers, smoked 1 to 10 cigarette/day; Moderate smokers, smoked 11 to 20 cigarette/day; heavy smokers, smoked more than 20 cigarette/day). Subjects were evaluated to determine the changes in vWF levels and TWBCS.

$3 \mathrm{ml}$ of venous blood was collected from each subject. $2 \mathrm{ml}$ in 3.8\% trisodium citrate $(9: 1 \mathrm{vol} / \mathrm{vol})$, kept on ice until centrifugation at $2500 \mathrm{~g}$ for 30 minutes at $4^{\circ} \mathrm{C}$, plasma samples were immediately frozen and stored at $-80^{\circ} \mathrm{C}$ for subsequent analysis; and $1 \mathrm{ml}$ in EDTA for the $\mathrm{ABO}$ blood grouping. Laboratory analysis was performed at the Department of Haematology, Faculty of Medical Laboratory Sciences, Alneelain University.

White cells count was determined by automated cell counter $\left(\right.$ Sysmex $^{\oplus}$ Kx21-N). Estimation of vWF was carried out using Enzyme Linked Immunosorbent Assay (ELISA), method with kit obtained from Technoclone GmbH Brunner str 67 1230, Vienna Austrla (Lot 3015983-014). Statistical analysis was performed using statistical package for social science (SPSS) software. Evaluation of patient's data was performed using the t-test and Pearson correlation test. Results with $\mathrm{P}$ value $<0.05$ were considered statistically significant. This study was approved by ethical committee of ministry of health, and informed consent was obtained from each participant before sample collection.

\section{Results}

In a total of one hundred subjects included in this study, all of them were Sudanese males, 50 were smokers and the other 50 were apparently healthy controls. The distribution of heavy, moderate and mild smokers in smokers group were 10 (20\%), 9 (18\%) and 31 (62) respectively.

The present study showed that the TWBCs (Mean \pm SD) was found to be 8.24 \pm 2.56 and $6.03 \pm 2.07)$ in smokers and nonsmokers respectively. TWBCs was found to be significantly higher in smoker group than nonsmokers $(P=0.000)$. The vWF Mean \pm SD was found to be $0.96 \pm 0.40$ and $0.64 \pm 0.21$ in smokers and nonsmokers respectively. vWF was found to be significantly higher in smoker group than nonsmoker groups $(\mathrm{P}=0.000)$ as showed in Table 1 .

Table 2 showed the comparison of mean TWBC count and mean vWF among different smoker groups (mild, moderate and heavy) and non-smoker group.

Table 3 showed that there is strong relationship between TWBC and vWF with cigarette consumption/day and the duration of smoking (Year).

Table 1. Comparing of TWBCs and vWF between smoker and nonsmoker groups.

\begin{tabular}{ccccc}
\hline Parameters & Grouping & N & Mean \pm SD & P-value \\
\hline \multirow{2}{*}{ T.WBC } & Smoker & 50 & $8.24 \pm 2.56$ & 0.000 \\
& Non-Smoker & 50 & $6.03 \pm 2.07$ & \\
vWF & Smoker & 50 & $0.96 \pm 0.40$ & 0.000 \\
& Non-Smoker & 50 & $0.64 \pm 0.21$ & \\
\hline
\end{tabular}


Table 2. Comparison of TWBC count and vWF levels between different groups of smoker and nonsmoker group.

\begin{tabular}{ccccc}
\hline Variables & Group & $\mathrm{N}(\%)$ & Mean $\pm \mathrm{SD}$ & P-value \\
\hline \multirow{3}{*}{ T.WBC } & Heavy smoker & $10(20 \%)$ & $8.48 \pm 1.75$ & 0.004 \\
& Moderate smoker & $9(18 \%)$ & $7.28 \pm 2.04$ & 0.033 \\
& Mild smoker & $31(62)$ & $6.15 \pm 2.16$ & 0.994 \\
& Nonsmoker & 50 & $6.03 \pm 2.00$ & \\
& Heavy smoker & $10(20 \%)$ & $0.95 \pm 0.40$ & 0.001 \\
vWF & Moderate smoker & $9(18 \%)$ & $0.71 \pm 0.13$ & 0.773 \\
& Mild smoker & $31(62)$ & $0.68 \pm 0.25$ & 0.745 \\
& Nonsmoker & 50 & $0.63 \pm 0.19$ & \\
\hline
\end{tabular}

Table 3. Correlations between TWBCS, vWF and duration of smoking and cigarette consumption.

\begin{tabular}{|c|c|c|c|c|c|}
\hline \multicolumn{2}{|c|}{ Parameters } & \multirow[t]{2}{*}{ T.WBC } & \multirow{2}{*}{$\begin{array}{l}\text { vWF } \\
0.293\end{array}$} & \multirow{2}{*}{$\begin{array}{c}\begin{array}{c}\text { Duration of } \\
\text { smoking }\end{array} \\
0.389\end{array}$} & \multirow{2}{*}{$\begin{array}{c}\begin{array}{c}\text { cigarette } \\
\text { consumption/day }\end{array} \\
0.462\end{array}$} \\
\hline 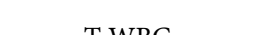 & $\mathrm{R}$-value & & & & \\
\hline $1 . \mathrm{V} V \mathrm{DC}$ & P-value & & 0.044 & 0.005 & 0.001 \\
\hline \multirow{2}{*}{ vWF } & R-value & 0.293 & & 0.295 & 0.387 \\
\hline & P-value & 0.044 & & 0.037 & 0.006 \\
\hline \multirow{2}{*}{ Duration of smoking } & R-value & 0.389 & 0.295 & & -0.276 \\
\hline & P-value & 0.005 & 0.037 & & 0.085 \\
\hline Cigarette & R-value & 0.462 & 0.387 & -0.276 & \\
\hline consumption/day & $\mathrm{P}$-value & 0.001 & 0.006 & 0.085 & \\
\hline
\end{tabular}

\section{Discussion}

Cigarette smoking is one of the major leading causes of death and essential public health problem in world over. We study the effects of cigarette smoking on the TWBC count and vWF levels. The study included 50 Sudanese smokers; their TWBC count and vWF levels were measured and compared with 50 age matched non-smokers as control. We observed a significant increase in the mean of the TWBC count. Our finding is consistent with other published reports [14] [15] [16]. Several studies have shown that WBC count is an independent predictor of atherosclerosis and cardiovascular disease [12] [13]. The high WBC count in our smoking subjects may suggest that they might be at greater risk for developing cardiovascular diseases than nonsmokers.

Mean vWF was significantly higher in smokers compared to nonsmokers, as previously reported [17]. The high levels observed in smoker group imply injury to the endothelium. It has been proposed that the increased level of vWF among smokers may be due to cytotoxic effects of lipid peroxidase formed by oxygen free radicals, and the effects of nicotine and carbon monoxide [14] [18] [19].

Increased TWBC count and vWF levels were significantly associated with the number of cigarettes smoked per day, and the duration of smoking, indicating that the association of the smoking with the increased TWBC count and vWF 
levels is a dose-dependent.

\section{Conclusion}

This study concluded that smoking potentially increases TWBC count and vWF level. Increased TWBC count and vWF level in the smokers is dose-dependent, which is directly associated with the smoking duration and frequency.

\section{References}

[1] Kume, A., Kume, T., Masuda, K., Shibuya, F. and Yamzaki, H. (2009) Dose-Dependent Effect of Cigarette Smoke on Blood Biomarkers in Healthy Volunteers: Observations from Smoking and Non-Smoking. Journal of Health Sciences, 55, 259 264. https://doi.org/10.1248/jhs.55.259

[2] Islam, M.M., Amin, M.R., Begum, S., Akther, D. and Rahman, A. (2007) Total Count of White Blood Cells in Adult Male Smokers. Journal of Bangladesh Society of Physiologist, 2, 49-53.

[3] Green, C.R. and Rodgman, A. (1996) The Tobacco Chemists' Research Conference: A Half Century Forum for Advances in Analytical Methodology of Tobacco and Its Products. Recent Advances in Tobacco Science, 22, 131-304.

[4] Gitte, R.N. (2011) Effect of Cigarette Smoking on Plasma Fibrinogen and Platelet Count. Asian Journal of Medical Sciences, 2, 181-184.

[5] Doll, R., Peto, R., Boreham, J. and Sutherland, I. (2004) Mortality in Relation to Smoking: 50 Years' Observations on Male British Doctors. The British Medical Journal, 328, 1519-1529. https://doi.org/10.1136/bmj.38142.554479.ae

[6] Blann, A.D. and McCollum, C.N. (1993) Adverse Influence of Cigarette Smoking on the Endothelium. Thrombosis and Haemostasis, 70, 707-711.

[7] Blann, A.D. and McCollum, C.N. (1994) Von Willebrand Factor, Endothelial Cell Damage and Atherosclerosis. European Journal of Vascular and Endovascular Surgery, 8, 10-15.

[8] Blann, A.D. (1993) Is Raised Von Willebrand Factor a Marker of Endothelial Cell Damage? Medical Hypotheses, 41, 419-424.

[9] Ruggeri, Z.M. and Zimmerman, T.S. (1981) The Complex Multimeric Composition of Factor VIII/vWF. Blood, 57, 1140-1143.

[10] Bongers, T.N., de Maat, M.P.M. and Mary-Lou, P.J. (2006) Van Goor, Vinod Bhagwanbali. Stroke, 37, 2672-2677.

[11] Sadler, J.E. (2009) Low Von Willebrand Factor: Sometimes a Risk Factor and Sometimes a Disease. Hematology. American Society of Hematology. Education Program, 106-112.

[12] Madjid, M., Awan, I., Willerson, J.T. and Casscells, S.W. (2004) Leukocyte Count and Coronary Heart Disease: Implications for Risk Assessment. Journal of the American College of Cardiology, 44, 1945-1956.

[13] Loimaala, A., Rontu, R., Vuori, I., Mercuri, M., Lehtimaki, T., Nenonem, A. and Bond, M. (2006) Blood Leukocyte Count Is a Risk Factor for Intimamedia Thickening and Subclinical Carotid Atherosclerosis in Middle-Aged Men. Atherosclerosis, 188, 363-369.

[14] Blann, A.D., Kirkpatrick, U., Devine, C., Naser, S. and McCollum, C.N. (1998) The Influence of Acute Smoking on Leucocytes, Platelets and the Endothelium. Atherosclerosis, 141, 133-139. 
[15] Smith, M.R., Kinmonth, A.L., Luben, R.N., Bingham, S., Day, N.E., Wareham, N.J., Welch, A. and Khaw, K.T. (2003) Smoking Status and Differential White Cell Count in Men and Women in the EPIC-Norfolk Population. Atherosclerosis, 169, 331-337.

[16] Wannamethee, S.G., Lowe, G.D., Shaper, A.G., Rumley, A., Lennon, L. and Whincup, P.H. (2005) Associations between Cigarette Smoking, Pipe/Cigar Smoking, and Smoking Cessation, and Haemostatic and Inflammatory Markers for Cardiovascular Disease. European Heart Journal, 26, 1765-1773. https://doi.org/10.1093/eurheartj/ehi183

[17] Kumari, M., Marmot, M. and Brunner, E. (2000) Social Determinants of Von Willebrand Factor: The Whitehall II Study. Arteriosclerosis, Thrombosis, and Vascular Biology, 20, 1842-1847. https://doi.org/10.1161/01.ATV.20.7.1842

[18] Blaes, N., Piovella, F., Samaden, A., BoutherinFalson, O. and Ricetti, M. (1986) Nicotine Alters Fibronectin and Factor VIII/vWF in Human Vascular Endothelial Cells. British Journal of Haematology, 64, 675-687. https://doi.org/10.1111/j.1365-2141.1986.tb02229.x

[19] Kalra, J., Chaudhary, A.K. and Prasad, K. (1991) Increased Production of Oxygen Free Radicals in Cigarette Smokers. International Journal of Experimental Pathology, 72, 1-7.

Submit or recommend next manuscript to OALib Journal and we will provide best service for you:

- Publication frequency: Monthly

- 9 subject areas of science, technology and medicine

- Fair and rigorous peer-review system

- Fast publication process

- Article promotion in various social networking sites (LinkedIn, Facebook, Twitter, etc.)

- Maximum dissemination of your research work

Submit Your Paper Online: Click Here to Submit

Or Contact service@oalib.com 